\title{
Efficacy and safety of TDF+FTC+EFV in naïve patients initiating HAART; an observational study comparing Atripla Vs Truvada/Sustiva exposure
}

\author{
Carlos Alberto Sanchez, Jose Medrano, Pablo Labarga, Eugenia Vispo, Aida Calviño, Luz Martín-Carbonero, \\ Pablo Barreiro*, Vicente Soriano
}

From $16^{\text {th }}$ International Symposium on HIV and Emerging Infectious Diseases Marseille, France. 24-26 March 2010

\section{Background}

Co formulation enhance adherence in HIV infected patients who initiate HAART. Aim of this study was to compare the efficacy and safety of Atripla vs Truvada plus Sustiva in naive HIV-infected patients.

\section{Methods}

This prospective and observational study was conducted at a referral outclinic in Madrid. All consecutive patients who initiated TDF+FTC+EFV coformulated (Atripla) as a first regim were compared to patients who initiated TDF +FTC (Truvada) plus EFV (Sustiva). Primary outcomes were time to viral suppression and immune recovery, assessed quarterly during regular follow up. Secondary outcomes were classified as drug-related adverse events and AIDS related events. Statistical analyses were realised using the Chi-square and the T-student test for categorical and continuous variables, respectively.

\section{Results}

The study population was composed by 33 patients included in the cohort of patients treated by Atripla and 72 patients included in the cohort of patients treated by Truvada plus Sustiva. In the Atripla cohort, mean age was 37,4 years, $97 \%$ were men, $46 \%$ were native Spaniards, $54 \%$ were MSM and $6 \%$ had a HCV coinfection. In this cohort, mean nadir CD4 count was 291 cells $/ \mu \mathrm{L}$ and mean viral load at baseline was 4,3 log. All variables were similarly distributed in both cohorts except for liver stiffness: $18 \%$ had a F4 Metavir score in the Atripla group and any case at this stage was reported in the Truvada+Sustiva group. RT sequencing was available at baseline for $67 \%$ in

\footnotetext{
* Correspondence: pablolabarga@gmail.com Hospital Carlos III, Madrid, Spain
}

patients initiating Atripla and for $75 \%$ in the other group. No major mutations were found and distribution was similar for minor mutations. All patients in both groups achieved viral suppression but time was inferior in the Atripla group $(2,7$ months vs $4,5, \mathrm{p}<0,005)$ and CD4 recovery was superior; 163 vs $148(\mathrm{p}<0,005)$. In both groups, $15 \%$ of patients presented CNS-related adverse events. It is noteworthy that one patient treated by Tuvada plus Sustiva presented overdose of EFV.

\section{Discussion}

In current clinical practice, $\mathrm{TDF}+\mathrm{FTC}+\mathrm{EFV}$ coformulated was as effective and safe as TDF+FTC and EFV.

Published: 11 May 2010

doi:10.1186/1742-4690-7-S1-P51

Cite this article as: Sanchez et al:: Efficacy and safety of TDF+FTC+EFV in naïve patients initiating HAART; an observational study comparing Atripla Vs Truvada/Sustiva exposure. Retrovirology 2010 7(Suppl 1):P51.

Submit your next manuscript to BioMed Central and take full advantage of:

- Convenient online submission

- Thorough peer review

- No space constraints or color figure charges

- Immediate publication on acceptance

- Inclusion in PubMed, CAS, Scopus and Google Scholar

- Research which is freely available for redistribution

Submit your manuscript at www.biomedcentral.com/submit
Biomed Central 